\title{
Peertechz
}

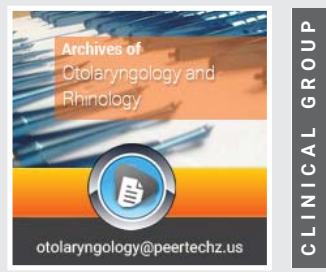

\section{Islanded supraclavicular artery flap: A versatile flap for oral reconstruction}

\author{
Farooq A Bhat, Bashir Ahmad Bhat* and Zahoor Ahmad \\ Naikoo
}

*Corresponding author: Dr. Bashir Ahmad Bhat, Department of Plastic surgery, SMHS hospital Srinagar, Jammu and Kashmir, 190011, India, Tel: +917006147775; E-mail: drbashirskims@gmail.com

Keywords: Supraclavicular artery; Island flap; Fasciocutaneous flap; Head and neck cancer; Reconstructive surgery https://www.peertechzpublications.com

\author{
Department of Plastic surgery, SMHS hospital Srinagar, Jammu and Kashmir, 190011, India
}

\begin{abstract}
Background: Supraclavicular flap is an excellent fasciocutaneous flap for head and neck reconstruction due to its close color and texture match. The aim of this study is to present supraclavicular artery island flap as an alternative choice in patients who need a free flap like radial forearm or ALT flap for reconstruction of oral mucosal defects, but are not fit for such microsurgical procedures.
\end{abstract}

Material and methods: This study was carried out in the Plastic Surgery Department of GMC Srinagar. It involved 12 patients, in whom supraclavicular artery island flap was done to reconstruct oral lining defects from January 2018 to December 2020.

Results: The study involved 12 patients ( 9 males and 3 females). Mean age was 26.5 years (range $12-57$ years). The cause of oral mucosal defect was post tumour resection in eight, fire arm injury in three, and corrosive injury in one patient. The following complications occurred: partial distal necrosis in 1 case, and donor site graft loss in 1case. All complications were managed conservatively.

Conclusion: This flap is thin, malleable, and is easily and rapidly harvested with minimal donor site morbidity. It can be used for single stage reconstruction of many types of head and neck defects.

\section{Introduction}

In treating patients with oral cancers, surgery is not limited to closure of the defect, but must allow three-dimensional functional and cosmetic rehabilitation with skin of a similar colour and texture to that of the recipient site. The closer the donor site is situated to the recipient site, the more likely the skin will present a comparable quality. Use of the skin of the shoulder, close to that of the face and neck, appears ideal, as it allows reconstruction of a functional anatomical unit with skin equivalent to the original skin. Although free flaps may be unavoidable for certain defects, a quicker alternative, such as regional flaps are a satisfactory choice in a patient with severe medical problems. An abnormal vascular history or finding may obviate certain reconstructive options. For example, a history of carotid disease or a bruit on examination may make free tissue transplantation a less desirable choice because of underlying vascular disease. In patients with contraindications to free tissue transfer or where free tissue transfer is risky, regional flaps are a viable option.

Regional flaps (Shoulder flaps) have been used as random flaps for head and neck reconstruction [1]. The use of the supraclavicular artery island flap as an axial pedicle flap was first published by Lamberty in 1979 [2]. A better understanding of the vascular anatomy of the region demonstrated the reliability and reproducibility of this flap. Pallua and his colleagues are credited with the first description of the flap as a "supraclavicular artery island flap [3]" and with a modification which eventually helped the establishment of this flap as a true contender in head and neck reconstruction. Since this description, there have been several publications in the literature describing the reliability of the flap in several options for reconstructing head and neck defects as well as in the anterior chest region [4]. The indications for supraclavicular artery island flap were therefore extended to head and neck reconstruction [3]. Di Benedetto et al. in 2005 
reported this flap as reliable for covering intraoral defects after oncologic resection [5]. Chiu, et al. described the use of the supraclavicular flap for functional pharyngeal reconstruction [6]. The supraclavicular artery flap has been widely used in head and neck reconstruction [7-9].

The supraclavicular artery island flap is harvested from the supraclavicular and deltoid regions. The blood supply of this flap is derived from the supraclavicular artery, a direct cutaneous branch of the transverse cervical artery in $93 \%$ of cases or the suprascapular artery in $7 \%$ of cases [3]. The constant supraclavicular artery measures 1 to $1.5 \mathrm{~mm}$ in diameter and allows the creation of a 3 to $4 \mathrm{~cm}$ pedicle. The artery arises $3 \mathrm{~cm}$ above the clavicle at a distance of about 8 $\mathrm{cm}$ from the sternoclavicular junction and about $2 \mathrm{~cm}$ from the sternocleidomastoid muscle. The supraclavicular artery anastomoses distally to branches of the posterior circumflex humeral artery, allowing the skin paddle to be extended from the supra-clavicular region to the lateral surface of the shoulder, beyond the deltoid muscle insertion. Two venae comitantes accompany the supraclavicular artery. One vein drains into the transverse cervical vein. The second vein drains into the external jugular vein or subclavian vein. The vascular territory of the supraclavicular artery extends from the supraclavicular region to the rotator cuff. The area of this angiosome is about $10 \mathrm{~cm}$ wide by $22 \mathrm{~cm}$ long [10]. The flap is harvested in a zone defined by the edge of the trapezius muscle posteriorly and a parallel line as far as the deltoid muscle anteriorly. The size of the paddle can range from 4 to $12 \mathrm{~cm}$ wide and 20 to $30 \mathrm{~cm}$ long [10].

\section{Method of flap harvest}

The patient is placed in the supine position a bolster is placed beneath the shoulder blades to expose the supraclavicular region. The patient's head is turned towards the opposite side of the flap donor site. The origin of the supraclavicular vessels is located in a triangle delineated by the posterior border of the sternocleidomastoid muscle medially, the external jugular vein posteriorly, and the median portion of the clavicle anteriorly. The flap is harvested in a zone defined by the edge of the trapezius muscle posteriorly and a parallel line as far as the deltoid muscle anteriorly. The size of the skin paddle is marked and skin, subcutaneous tissue and fascia are incised over the deltoid muscle. Fascia may be sutured to the skin by a suture. Dissection is continued in the subfascial plane over the deltoid and the flap is harvested from distal to proximal. Dissection in the subfascial plane over the deltoid muscle allows harvesting of the overlying fascia to ensure better vascular protection (perifascial anastomotic network). Perforating vessels of the deltoid muscle are cauterized during harvesting of the paddle and dissection is easily continued as far as the supraclavicular fossa. The pedicle is identified by transillumination in the middle third of the flap. The skin and subcutaneous tissue are carefully incised to preserve the pedicle according to the desired dimensions of the paddle. The spinal nerve, which crosses the deep portion of the posterior triangle of the neck underneath the sternocleidomastoid muscle, is identified and preserved as far as its point of entry into the trapezius muscle.
Depending on the defect to be covered and the required arc of rotation, the vascular pedicle can be cautiously dissected as far as its origin). Section of the transverse cervical artery after its division into a supraclavicular cutaneous branch releases the pedicle and increases the arc of rotation of the flap.

\section{Material and methods}

This study was carried out in the Plastic Surgery Department of GMC Srinagar. It involved 12 patients, in whom supraclavicular artery island flap was done to reconstruct oral lining defects from January 2018 to December 2020.

\section{Results}

From January 2018 to December 2020, supraclavicular island flap was used for reconstruction of oral cavity mucosal defects. The study involved 12 patients ( 9 males and 3 females). Mean age was 26.5 years (range 12-57 years). Mean size of the flap was $5.5 \mathrm{~cm}$ wide and $24.3 \mathrm{~cm}$ long. The cause of oral mucosal defect was post tumour resection in eight, fire arm injury in three, and corrosive injury in one patient. The average harvest time was 50 minutes. The flap was islanded on its fascial pedicle in all cases and tunneled through neck. The flap was used to resurface floor of mouth in 10 patients, while as to cover buccal sulcus in 2 patients. The flap Donor sites could be closed primarily after undermining in two flaps and covered with STSG in ten flaps. The following complications occurred: partial distal necrosis in 1 case, and donor site graft loss in 1case. All complications were managed conservatively Figures 1-3.

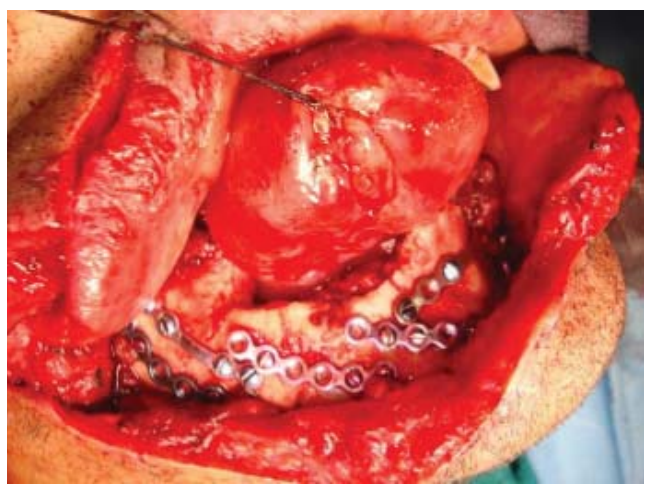

Figure 1: Defect in floor of mouth with comminuted Fracture of mandible.

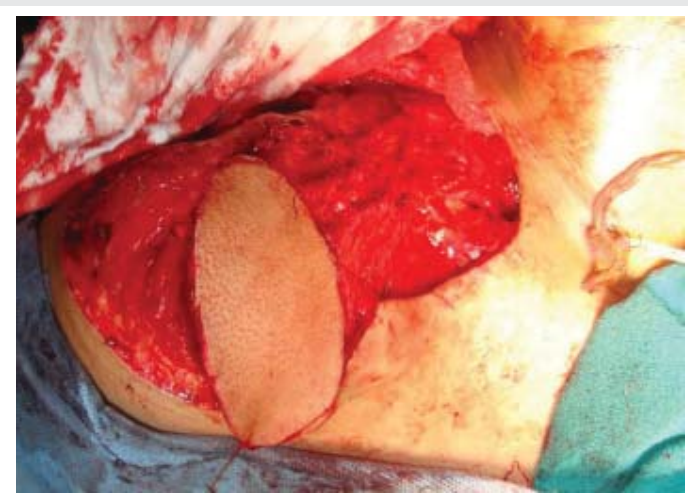

Figure 2: Islanded SCA Flap harvested. 


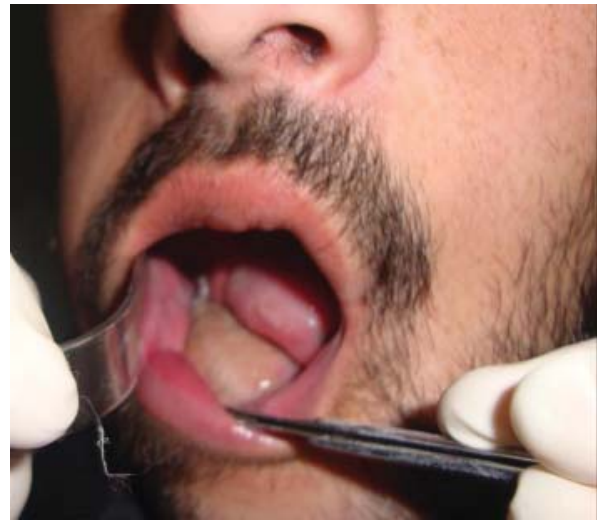

Figure 3: Post operative view after 6 months.

\section{Discusscion}

Reconstruction of the soft tissues of the oral cavity after cancer resection is often challenging and requires the use of local, regional or free flaps to ensure anatomical, functional and cosmetic rehabilitation. A thin, malleable flap with a texture and colour similar to those of the recipient site is ideal for repair of oral defects.

Regional myocutaneous flaps are difficult to position in certain sites (e.g. oral cavity). Sacrifice of a muscle at the donor site is associated with morbidity and sequelae. Free flaps (forearm flap, anterolateral thigh flap) provide thin, flexible, well vascularized tissue to cover large defects. However, not all patients are eligible for this long surgery, which requires an experienced multidisciplinary team. In these difficult cases, regional flaps remain the reference technique and the supraclavicular artery island flap is an ideal solution for these patients, as it is a reliable flap with a constant neurovascular pedicle.

Flap harvesting is easy and rapid, depending on the surgeon's experience5. Due to its rapid harvesting and the site of the flap in a usually neutral region (not operated, not irradiated), use of this flap can be considered in multi operated patients or patients with major comorbidities not fit for free tissue transfer. The supraclavicular artery island flap is thin, hairless, with a colour and texture similar to those of the face. The thin dermis and the absence of body hair facilitate use of this flap in the oral cavity and oropharynx. This flap can be deepithelialized and then tunneled through the neck to be used as lining in oral cavity [11]. Supraclavicular innervation can be preserved during flap dissection, allowing sensory reconstructions, for example in a neopharynx. Island harvesting of flap, allows the coverage of defects ranging from the middle third of the face to the mediastinum [12]

Neck dissection (Level V) can damage the pedicle, as this dissection is rarely performed and, when it is necessary, the surgeon can usually preserve the vascular pedicle of this flap. A history of level V neck dissection or radical dissection does not constitute a contraindication to the use of this flap. Duplex ultrasound examination can be performed before harvesting the flap to ensure the presence and integrity of the vascular pedicle. The supraclavicular artery island flap can be an alternative to the myocutaneous flap or pectoralis major muscle flap. With time, the pectoralis major muscle atrophies and forms an adhesion responsible for decreased range of neck flexion and extension. The absence of the pectoralis major muscle in the shoulder results in a reduction of the range of external and internal rotation and adduction. These sequelae limit the patient's activity. Harvesting of a supraclavicular artery island flap preserves the muscles and motor nerves of the shoulder and therefore preserves the normal range of motion of the shoulder [13]. The donor site is self-closing for flaps up to16 $\mathrm{cm}$ wide [3]. Local flaps or skin graft have also been proposed to ensure closure of the donor site. The longterm appearance of the scar is satisfactory, although widening of the scar may be observed. Patients report mild-to-moderate rapidly resolving shoulder pain after flap harvesting. The donor site surgical morbidity is low, associated with a short hospital stay and the functional results are equivalent to those of other techniques. This flap constitutes an excellent option for patients with vascular disease preventing microsurgery, multi operated patient or patients with advanced cancer [14].

\section{Conclusion}

The supraclavicular artery island flap is a thin, malleable fasciocutaneous flap that is easily and rapidly harvested, with a reliable pedicle and minimal donor site morbidity. It can be used for one-step innervated reconstructions of many types of oral lining defects. It constitutes an alternative to local flaps, while providing equivalent functional results.

\section{References}

1. Ross RJ, Baillieu CE, Shayan R, Leung M, Ashton MW (2014) The anatomical basis forimproving the reliability of the supraclavicular flap. J Plast Reconstr Aesthet Surg 67: 198-204. Link: https://bit.ly/3e5Selm

2. Lamberty BG (1979) The supra-clavicular axial patterned flap. Br J Plast Surg 32: 207-212. Link: https://bit.ly/2Rcw6wW

3. Pallua N, Magnus Noah E (2000) The tunneled supraclavicular island flap: an opti-mized technique for head and neck reconstruction. Plast Reconstr Surg 105: 842-851. Link: https://bit.ly/3nEd9z3

4. Alves HR, Ishida LC, Ishida LH, Besteiro JM, Gemperli R, et al. (2012) A Clinica experience of the supraclavicular flap used to reconstruct head and neck defects in late-stage cancer patients. J Plast Reconstr Aesth Surg 65: 13501356. Link: https://bit.ly/3u8GDYv

5. Di Benedetto G, Aquinati A, Pierangeli M, Scalise A, Bertani A (2005) From the "charretera" to the supraclavicular fascial island flap: revisitation and further evolution of a controversial flap. Plast Reconstr Surg 115: 70-76. Link: https://bit.ly/3aTrnXK

6. Alves HR, Ishida LC, Ishida LH, Besteiro JM, Gemperli R, et al. (2012) A clinica experience of the supraclavicular flap used to reconstruct head and neck defects in late stage cancer patients. J Plast Reconstr Aesthet Surg 65: 1350 1356. Link: https://bit.ly/3eJfjcH

7. Wirtz NE, Khariwala SS (2017) Update on the supraclavicular flap. Curr Opin Otolaryngol Head Neck Surg 25: 439-444. Link: https://bit.ly/3e49Y0C

8. Kokot N, Mazhar K, Reder LS, Peng GL, Sinha UK (2013) The supraclavicular artery island flap in head and neck reconstruction: applications and limitations. JAMA Otolaryngol Head Neck Surg 139: 1247-1255. Link: https://bit.ly/3e8aLNX 
9. Rashid M, Zia-ul-Islam M, Bhatti AM (2006) The 'expansile' supraclavicular artery flap for release of post-burn neck contractures. J Plast Reconstr Aesthet Surg 59: 1094-1101. Link: https://bit.ly/3t92PR5

10. Pallua N, Machens HG, Rennekampff O, Becker M, Berger A (1997) The fasciocuta-neous supraclavicular artery island flap for releasing postburn mentosternalcontractures. Plast Reconstr Surg 99: 1878-1884. Link: https://bit.ly/2PGxfMM

11. Bach CA, Wagner I, Darmon S, Denoux Y, Chabolle F (2015) Versatility of the supra-clavicular artery island flap for post-radiation tracheoesophageal fistula. HeadNeck Oncol.
12. Balakrishnan TM, Sivarajan N (2012) Anatomical study of supraclavicular perforator artery and its clinical application as sensate supraclavic supraclavicular artery propeller flap in the reconstruction of post burns scar contracture neck. Indian J Sci Technol 5: 3137-3141. Link: https://bit.ly/3gU2rU2

13. Herr MW, Bonanno A, Montalbano LA, Deschler DG, Emerick KS (2014) Shoulderfunction following reconstruction with the supraclavicular artery island flap. Laryngoscope 124: 2478-2483. Link: https://bit.ly/3eO6b6C

14. Nthumba PM (2012) The supraclavicular artery flap: a versatile flap for neck andorofacial reconstruction. J Oral Maxillofac Surg 70: 1997-2004. Link: https://bit.ly/3e6qzRf

\section{Discover a bigger Impact and Visibility of your article publication with}

\section{Peertechz Publications}

\section{Highlights}

* Signatory publisher of ORCID

* Signatory Publisher of DORA (San Francisco Declaration on Research Assessment)

* Articles archived in worlds' renowned service providers such as Portico, CNKI, AGRIS, TDNet, Base (Bielefeld University Library), CrossRef, Scilit, J-Gate etc.

* Journals indexed in ICMJE, SHERPA/ROMEO, Google Scholar etc.

* OAI-PMH (Open Archives Initiative Protocol for Metadata Harvesting)

* Dedicated Editorial Board for every journal

* Accurate and rapid peer-review process

* Increased citations of published articles through promotions

* Reduced timeline for article publication

Submit your articles and experience a new surge in publication services (https://www.peertechz.com/submission).

Peertechz journals wishes everlasting success in your every endeavours.

Copyright: @ 2021 Bhat FA, et al. This is an open-access article distributed under the terms of the Creative Commons Attribution License, which permits unrestricted use distribution, and reproduction in any medium, provided the original author and source are credited.

Citation: Bhat FA, Bhat BA, Naikoo ZA (2021) Islanded supraclavicular artery flap: A versatile flap for oral reconstruction. Arch Otolaryngol Rhinol 7(2): 012-015. DOI: https://dx.doi.org/10.17352/2455-1759.000139 